25 Bifulco A, Brown GW, Adler Z. Early sexual abuse and clinical depression in adult life. Br J Psychiatry 1991; 159: 115-22.

26 Saykin AJ, Gur RC, Gur RE, Mozley PD, Mozely LH, Resnick SM, et al. Neuropsychological functioning in schizophrenia: selective impairment in memory and learning. Arch Gen Psychiatry 1991; 48: 618-24.

27 Darves-Bornoz JM, Lemperiere T, Degiovanni A, Gaillard P. Sexual victimisation in women with schizophrenia and bipolar disorder. Soc Psychiatry Psychiatr Epidemiol 1995; 30: 78-84.

28 May-Chahal C, Cawson P. Measuring child maltreatment in the United Kingdom: a study of the prevalence of child abuse and neglect. Child Abuse Negl 2005; 29: 969-84.

29 Plomin R. Genetics and Experience: The Interplay between Nature and Nurture. Sage, 1994

30 Croudace TJ, Kayne R, Jones PB, Harrison GL. Non-linear relationship between an index of social deprivation, psychiatric admission prevalence and the incidence of psychosis. Psychol Med 2000; 30: 177-85.

31 Sidebotham $\mathrm{P}$, Heron J, ALSPAC Study Team. Child maltreatment in the 'children of the nineties': a cohort study of risk factors. Child Abuse Negl 2006; 30: 497-522.

32 Houston JE, Murphy J, Adamson G, Stringer M, Shevlin M. Childhood sexual abuse, early cannabis use, and psychosis: testing an interaction model based on the National Comorbidity Survey. Schizophr Bull 2008; 34: 580-5.

33 Bebbington $\mathrm{P}$, Wilkins $\mathrm{S}$, Jones $\mathrm{P}$, Foerster A, Murray R, Toone B, et al. Life events and psychosis. Initial results from the Camberwell Collaborative Psychosis Study. Br J Psychiatry 1993; 162: 72-9.

34 Desai S, Arias I, Thompson MP, Basile KC. Childhood victimization and subsequent adult revictimization assessed in a nationally representative sample of women and men. Violence vict 2002; 17: 639-53.

35 Gracie A, Freeman D, Green S, Garety PA, Kuipers E, Hardy A, et al. The association between traumatic experience, paranoia and hallucinations: a test of the predictions of psychological models. Acta Psychiatr Scand 2007; 116: $280-9$.

36 Berry K, Barrowclough C, Wearden A. A review of the role of adult attachment style in psychosis: unexplored issues and questions for further research. Clin Psychol Rev 2007; 27: 458-75.

37 Bifulco A, Kwon J, Jacobs C, Moran PM, Bunn A, Beer N. Adult attachment style as mediator between childhood neglect/abuse and adult depression and anxiety. Soc Psychiatry Psychiatr Epidemiol 2006; 41: 796-805.
38 Whitfield C, Dube S, Felitti V, Anda R. Adverse childhood experiences and hallucinations. Child Abuse Negl 2005; 29: 797-810.

39 Spataro J, Mullen PE, Burgess PM, Wells DL, Moss SA. Impact of child sexual abuse on mental health: prospective study in males and females. $\mathrm{Br} \mathrm{J}$ Psychiatry 2004; 184: 416-21.

40 McFadyen-Ketchum SA, Bates JE, Dodge KA, Pettit GS. Patterns of change in early childhood aggressive-disruptive behaviour: gender differences in predictions from early coercive and affectionate mother-child interactions. Child Dev 1996; 67: 2417-33.

41 Dodge KA, Pettit GS, McClaskey CL, Brown M. Social competence in children. Monogr Soc Res Child Dev 1986; 51 (2, Serial No. 213).

42 Frith CD. The Cognitive Neuropsychology of Schizophrenia. Psychology Press, 1992.

43 Eisenberg N, Fabes RA, Nyman M. Bernzweig J, Pinuelas A. The relations of emotionality and regulation to children's anger-related reactions. Child Dev 1994; 65: 109-28.

44 Barr CS, Newman TK, Schwandt M, Shannon C, Dvoskin RL, Lindell SG, et al. Sexual dichotomy of an interaction between early adversity and the serotonin transporter gene promoter variant in rhesus macaques. Proc Natl Acad Sci USA 2004; 101: 12358-63.

45 Kessler RC, Sonnega A, Bromet E, Hughes M, Nelson CB. Posttraumatic stress disorder in the National Comorbidity Survey. Arch Gen Psychiatry 1995; 52: 1048-60.

46 Cole T, Sapp GL. Stress, locus of control, and achievement of high school seniors. Psychol Rep 1988; 63: 355-9.

47 De Bellis MD, Chrousos GP, Dorn LD, Burke L, Helmers K, Kling MA, et al. Hypothalamic-pituitary-adrenal axis dysregulation in sexually abused girls. J Clin Endocrin Metabol 1994; 78: 249-55.

48 Moore $H$, West AR, Grace AA. The regulation of forebrain dopamine transmission: relevance to the pathophysiology and psychopathology of schizophrenia. Biol Psychiatry 1999; 46: 40-55.

49 Andrews B, Brewin CR, Rose S. Gender, social support, and PTSD in victims of violent crime. J Trauma Stress 2003; 16: 421-7.

50 Ahern J, Galea S, Fernandez WG, Koci B, Waldman R, Vlahov D. Gender, social support, and posttraumatic stress in postwar Kosovo. J Nerv Ment Dis 2004; 192: 762-70.

\title{
100 Catatonia
}

Catatonia, a motor dysregulation syndrome, was described by Karl Kahlbaum in 1874. Emil Kraepelin buried catatonia in schizophrenia, where it has been ignored for more than a century. When looked for today, catatonia is found in $10 \%$ of acute psychiatric admissions, most often in persons with mood disorder or toxicity. Catatonia is readily diagnosable, verifiable by a lorazepam challenge test, and eminently and rapidly treatable even in its lethal forms, with lorazepam or electroconvulsive therapy. Prompt recognition and treatment saves lives. It is time to bury schizophrenia, catatonic type and resurrect catatonia into its own home in the psychiatric classification. 